\title{
Editorial
}

\section{Strategic B2B pricing}

Journal of Revenue and Pricing Management (2012) 11, 1-3. doi:10.1057/rpm.2011.46

Marketing activities are in rapid evolution. Firms increasingly co-create values together with their customers (Payne et al, 2008); firms not only adapt to customer needs, they increasingly shape customer needs and alter market configurations (Storbacka and Nenonen, 2011). Firms finally increasingly need to quantify customer value and document their own contribution to the customer's profitability (Anderson et al, 2006). What is the role of the pricing function in this context?

Pricing is an element of the marketing mix. As such, academics and practitioners frequently treat pricing as tactical activity, after issues related to marketing strategy - segmentation, targeting and positioning - have been addressed.

In this special issue, we shed light on research summarizing how firms treat the pricing function in industrial companies as a strategic activity strategic from at least two different perspectives. First, as strategic in the sense of seeing pricing as an integral part of firm strategy. Second, strategic as encompassing a resource and activity configuration that is valuable, rare, difficult to imitate, non-substitutable and embedded in the firm's organization (Barney, 1991), and thus enabling a firm to build a competitive advantage and to achieve superior profitability as a result of pricing activities.

The paper by Magnus Johansson, Niklas Hallberg, Andreas Hinterhuber, Mark Zbaracki and Stephan Liozu highlights the strategic role of pricing capabilities and shows how firms develop and organizationally embed pricing activities to gain a sustainable competitive advantage. Pricing capabilities encompass pricing setting within the firm and price setting vis-à-vis customers (Dutta et al, 2003). The quantification of customer value is a prerequisite for the development of effective pricing strategies and pricing capabilities.

Stephan Liozu, Andreas Hinterhuber, Richard Boland and Sheri Perelli examine to which extent an academically rigorous and practically relevant conceptualization of customer value is present in US industrial firms. The authors find that a large share of companies practicing cost- or competition-based pricing has an ill-defined understanding of customer value. The authors thus conjecture that the lack of an academically rigorous understanding of customer value in industrial firms may be one factor contributing to the widespread, but suboptimal (Backman, 1953) adoption of cost-based or competition-based pricing approaches.

Rafael Farres, a practicing executive, further investigates the role of customer value-based pricing in industrial companies. In this practice article, the author makes it clear that even research-intensive, innovative companies should adopt a variety of alternative pricing strategies across their product and service portfolio. The author highlights firm and environmental conditions, which make valuebased pricing particularly suitable and illuminates under which conditions cost- and competition-based pricing approaches are appropriate for industrial firms.

Bradley Gale and Donald Swire illustrate how a customer value map can be constructed to compare customer-perceived benefits against 
purchase costs to derive an overall cost/benefit ratio of alternative products. Value maps translate product features into customer benefits and customer-perceived value, thus facilitating the adoption of customer value-based pricing, both for existing products as well as for new products. Other researchers (Sinha and DeSarbo, 1998) have shown how this map can be further developed into a latent structure, multidimensional scaling vector model with more than two dimensions. The widespread adoption of customer value maps by consultants (Leszinski and Marn, 1997; Baker et al, 2010) is a testimony to their high relevance in industrial pricing practice.

Tim Smith suggests treating price setting, discounting and price structure differently depending on the value and volume of transactions in industrial markets.

Magnus Johansson and Linn Andersson illustrate the implications of alternative value creation logics on pricing and customer value measurement. The authors build on Thompson (1967) and his long-linked, intensive and mediating technologies and on Stabell and Fjeldstad (1998) and their alternative business models of a value shop, a value chain and a value network; the authors then show the importance of a customer-specific assessment of customer willingness to pay in the business model of a value shop, where customer value is co-created. The main contribution of this article is the critical examination of the implications of alternative value configurations on pricing strategies and on relevant benchmarks to assess customer value.

Finally, in a Futures paper, Todd Snelgrove, a practitioner, traces the past and present of total cost of ownership (TCO) approaches and highlights in which direction TCO could evolve. As the 'sum of purchase price plus all expenses incurred during the productive lifecycle of a product minus its salvage or resale price' (Anderson and Narus, 2004), this approach is exclusively concerned with the cost side of customer value and neglects the value of customer-specific benefits (Anderson and
Narus, 2004). In this article, the author shows how TCO approaches can be expanded to incorporate the value of customer-specific benefits. The contribution of this article is thus to illuminate that TCO can be compatible with customer value-based pricing.

In this volume, we further find three articles published outside this special issue. Brenda Kahn and Philip Kahn analyze city-pair airline price data and find that airlines charge a significant price premium for flights between two gateway hubs over flights between a nongateway hub and a gateway hub, an indication that airlines may use hub-pricing to discriminate against less price sensitive international travelers.

Olivier d'Huart and Peter Belobaba use simulation to show that revenue management systems that unconstrain demand forecasts result in double counting of demand, thus overestimating forecasted demand resulting in smaller booking limits for lower fare classes than in the case of a monopolist (with perfect insight into true industry unconstrained demand). The authors point out ways to account for passenger spill between airlines.

Alwin Haensel, Michael Mederer and Henning Schmidt present a stochastic programming approach for a car rental network where capacity between alternative rental stations can be easily adjusted. The authors find that the stochastic version outperforms the deterministic version.

Industrial pricing has evolved. In light of the marketing challenges outlined above, we trust that the articles in this special issue contribute further to the strategic role of pricing in both academic research and business practice.

\section{REFERENCES}

Anderson, J. and Narus, J. (2004) Business Market Management: Understanding, Creating, and Delivering Value, 2nd edn. Upper Saddle River, NJ: Prentice-Hall.

Anderson, J.C., Narus, J.A. and Van Rossum, W. (2006) Customer value propositions in business markets. Harvard Business Review 84(3): 90.

Backman, J. (1953) Price Practices and Policies. New York: Ronald Press. 
Baker, W.L., Marn, M.V. and Zawada, C.C. (2010) The Price Advantage, Vol. 535, 2nd edn. Hoboken, NJ: Wiley.

Barney, J. (1991) Firm resources and sustained competitive advantage. Journal of Management 17(1): 99-120.

Dutta, S., Zbaracki, M.J. and Bergen, M. (2003) Pricing process as a capability: A resource based perspective. Strategic Management Journal 24(7): 615-630.

Leszinski, R. and Marn, M.V. (1997) Setting value, not price. McKinsey Quarterly 1(2): 98-115.

Payne, A.F., Storbacka, K. and Frow, P. (2008) Managing the co-creation of value. Journal of the Academy of Marketing Science 36(1): 83-96.

Sinha, I. and DeSarbo, W.S. (1998) An integrated approach toward the spatial modeling of perceived customer value. Journal of Marketing Research 35(5): 236-249.

Stabell, C.B. and Fjeldstad, Ø.D. (1998) Configuring value for competitive advantage: On chains, shops, and networks. Strategic Management Journal 19(5): 413-437.

Storbacka, K. and Nenonen, S. (2011) Scripting markets: From value propositions to market propositions. Industrial Marketing Management 40(2): 255-266.
Thompson, J.D. (1967) Organizations in Action. New York: McGraw Hill.

Andreas Hinterhuber ${ }^{\mathrm{a}, \mathrm{b}}$ ${ }^{a}$ Hinterhuber \& Partners and Bocconi University, Milano, Italy E-mails: andreas@hinterhuber.com; hinterhuber@unibocconi.it ${ }^{\mathrm{b}}$ Falkstrasse 16, Innsbruck, Austria

Stephan M. Liozu ${ }^{\mathrm{c}, \mathrm{d}}$

${ }^{c}$ ARDEX Americas and Case Western Reserve University, Cleveland, Ohio E-mail:Sliozu@case.edu ${ }^{\mathrm{d}}$ Ardex Drive, Aliquippa, Pittsburgh, USA 